\title{
Estimation of Genetic Variance and Broad Sense Heritability for Sugarcane
}

\author{
Khaled, K. A. M.; M. S. Saleh, E.A.M. Amer 1
}

\begin{abstract}
The present study carried out at Giza Agricultural Research Station, Giza, Egypt during 2010/2011 and 2011/2012 seasons. Five sugarcane genotypes (G.T.54-9, G.84-47, G.74-96, G.98-28 and G.98-24) conducted for estimating the broad sense heritability, genetic, environmental and phenotypic variances for yield, yield components and some quality characteristics.

The obtained results showed that G.98-28 genotype gave the highest value of stalk diameter, while G.84-47 genotype surpassed the other four genotypes in the number of millable cane $/ \mathrm{m}^{2}$, millable cane length, cane and sugar yields/fed in both seasons as well as Brix, sucrose, and sugar recovery percentage in second season. Meanwhile, genotype G.98-24 recorded the highest values of Brix, sucrose, and sugar recovery percentage in $1^{\text {st }}$ season.

Broad sense heritability was found to be ranged from 91.1\% for cane yield and millable cane diameter to $59.4 \%$ for number of millable cane. The results revealed that the broad sense heritability shown to be high. The genetic variance ranged from 0.2 for millable cane diameter to 82.91 for millable cane highest. The genotypic coefficient of variation (GCV \%) for the studied characteristics ranged from 3.84 calculated for millable cane highest to 28.67 for sugar yield. The phenotypic coefficient of variations (PCV $\%$ ) ranged from $4.72 \%$ for millable cane highest to 31.8 for sugar yield. Therefore, the improvement of breeding program for high number of millable canes, cane yield and sugar yield will be more effective than that for increasing cane yield. The present study suggests that sugar cane genotype improvement will have genetic advance in number of millable canes, cane yield and sugar yield than that cane yield.
\end{abstract}

\section{INTRODUCTION}

Sugarcane breeding program places considerable emphasis on producing new high yielding genotypes, resistant to diseases, insects and characterized with high rationing ability. Recently, Sugar Crops Research Institute has reached many promising sugarcane genotypes characterized with not only high cane yield but also good quality traits throughout several stages of selection.

Sugarcane genotype is the corner stone to minimize the gap between production and consumption of sugar. Differences among genotypes in yield, its components and quality characteristics were reported by (Ahmed, 2003; El-Shafai and Ismail 2006; Ismail and El-Sogheir
2008). Sugar cane yield is a polygenic character that highly affected by environmental conditions. Therefore, it is essential to know that the improvement of any character depends on the interaction between genes controlling this character and proper environmental conditions. Comstock and Moll (1963) classified the environment in two categories, macro and micro environmental variations. Macro environmental variation is caused by the fluctuation in variables that have large and easily recognized variation (i.e. years, locations, planting dates and plant density); whereas micro environmental variation arises from plant to plant and genotype to genotype variations within macro environments. Allam et al (1974) reported that a highly significant difference among clones was noted for the three variables measured, M.T. /ha, S/M.T., and S/ha, within all three cane types (plant, first-stubble and second. stubble). These authors reported that heritability was $(0.78,0.83$, and 0.75$)$ for plant cane, $(0.87,0.86$, and 0.82$)$ for first stubble, and $(0.90,0.89,0.87)$ for second stubble. The heritability estimates increased from plant to first stubble to second - stubble cane for all traits. Hogarth (1981) estimated that the broad sense heritability based on a plot mean was $(75 \%)$ for Brix, $(87 \%)$ for stalk diameter and $(63 \%)$ for stalk length, also he obtained high genetic variability for total soluble solids and cane yield. Kang et al (1983) estimated high broad sense heritability in two bi-parental crosses based on plot means for various traits, which was $84 \%$ for plant height, $94 \%$ for stalk diameter, $93 \%$ for stalk weight, and $91 \%$ for sucrose content. Kang et al (1987) mentioned that estimates of genetic and genotype $\mathrm{X}$ environment are needed to help optimize resource allocation across locations or years. Chang (1996) estimated $0.955,0.9 \cdot 14$ and 0.965 broad sense heritability for Brix, purity and sugar content, respectively. El-Taib et al (2005) evaluated some selected of sugar cane genotypes of diverse origin. They found significant and highly significant differences between environment and genotype $\mathrm{X}$ environment interaction for stalk weight, number of millable cane (1000/per fed), net cane yield ( $\mathrm{t} / \mathrm{fed})$, theoretical sugar recovery $\%$, and sugar yield (t/fed). Ghura (2005) found that the broad sense heritability ranged from $90 \%$ for stalk diameter and sucrose percentage to $78 \%$ for purity $\%$. The results revealed that the broad sense heritability shown to be high. She mentioned that genetic variance

\footnotetext{
${ }^{1}$ Genetic and Breeding Department, Sugar Crops Res. Inst., ARC Giza, Egypt

Received Febuary 14, 2013, Accepted March30, 2013
} 
ranged fro. 0.209 for stalk diameter to 934.51 for stalk length. The genotypic coefficient of variability (GCV $\%$ ) for the seven studied character ranged from $9.27 \%$ calculated for total soluble solids percent (Brix) to $32.7 \%$ for stalk weight. The phenotypic coefficient of variability (PCV \%) ranged from $10.02 \%$ to $35.14 \%$ for total soluble solids percent (Brix) and stalk weight; respectively.

\section{MATERIALS AND METHODS}

The present study carried out at Sabahia Agricultural Research Station, Alexandria Governorate, Egypt during 2010/2011 and 2011/2012 seasons. Five sugarcane genotypes (G.T. 54-9, G.84-47, G.74-96, G.98-28 and G.98-24) were employed for estimating the broad sense heritability, genetic, environmental and phenotypic variances for yield, yield component and some quality characteristics. Planting date took place in the first week of March, in both seasons. Each genotype sown in plots containing six ridges, one meter in width and seven meters in length. The distance between cuttings was $30 \mathrm{~cm}$. Each cutting contained two buds. The plot area was $42.0 \mathrm{~m}^{2}(6.0 \mathrm{~m} \times 7.0 \mathrm{~m})$. Harvest took place thirteen months after planting. Thirty plants taken randomly from each plot to study the following characters: Number of millable canes $/ \mathrm{m}^{2}$, Millable cane height $(\mathrm{cm})$, Millable cane diameter $(\mathrm{cm})$, Brix percentage, Sucrose percentage, Sugar recovery percentage, Cane yield (ton/fed) and Sugar yield (ton/fed). Split-plot design in three replications used. All other agricultural practices needed for growing sugar cane crop applied as recommended.

\section{Recorded data:}

The following characteristics were estimated at harvest in samples, each of twenty millable canes represent the following measurements:

1. Number of millable canes $/ \mathrm{m}^{2}$.

2. Millable cane height $(\mathrm{cm})$ measured from soil surface up to the top visible dewlap.

3. Millable cane diameter $(\mathrm{cm})$ measured at the middle part of stalks.

4. Total soluble solids (TSS \%) or Brix percentage in cane juice was measured using Hand Refractometer.

5. Sucrose percentage in cane juice was determined using "Saccharemeter" according to A.O.A.C. (1995).

6. Sugar recovery percentage calculated according to the following equation as described by Yadav and Sharma (1980).

Sugar recovery $\%=$ [sucrose $\%-0.4$ (brix $\%$ - sucrose $\%)] \times 0.73$.
7. Cane yield (ton/fed) calculated based on plot area.

8. Sugar yield (ton/fed) estimated as follows:

Sugar yield $($ ton/fed $)=$ cane yield $($ ton/fed $) \times$ sugar recovery $\%$.

\section{Statistical analysis}

The collected data statistically analyzed according to the method of Snedecor and Cochran (1981). Least significant difference test (LSD) at 5\% level of significance used to compare means.

The form of the variance analysis and the mean square expectations from which estimates of variance components obtained presented in Table (1). Separate estimates of the components of variation in each mean square expectation calculated to evaluate the magnitude of the different effects.

Variance components and the expected composition of the mean squares determined according to Miller et al (1959),

The phenotypic variance estimated by the following formula as outlined by Miller et al 1959 and Comstock and Moll 1963.

- Heritability in broad sense $\mathrm{h}_{\mathrm{b}}{ }^{2}=\left(\delta^{2} \mathrm{~g} / \delta^{2} \mathrm{ph}\right) \times 100$

- Genotypic coefficient of variation \% $(\mathrm{GCV} \%)=$ $\left(\sqrt{\delta^{2}} g / \mathrm{X}\right) \times 100$

- Phenotypic coefficient of variation \% (PCV \%) = $\left(\sqrt{\delta^{2}} p h / \mathrm{X}\right) \mathrm{x} 100$

Where $\mathrm{g}$ is number of genotypes, $\mathrm{y}=$ number of years, $\delta^{2} \mathrm{e}=$ error variance; $\sigma^{2} \mathrm{~g}, \sigma^{2} \mathrm{gy}$ are the variance attributed to genotypes, genotypes x years, respectively.

\section{RESULTS AND DISCUSSIONS}

Five sugarcane genotypes (G.T. 54-9, G.84-47, G.74-96, G.98-28 and G.98-24) were used for estimating the broad sense heritability, genetic, environmental and phenotypic variances for yield, yield component and some quality characteristics. Split-plot design in three replications used. All other agricultural practices needed for growing sugar cane crop applied as recommended. Thirty plants taken randomly from each plot to study the following characters: Number of millable canes $/ \mathrm{m}^{2}$, Millable cane height $(\mathrm{cm})$, Millable cane diameter $(\mathrm{cm})$, Brix percentage, Sucrose percentage, Sugar recovery percentage, Cane yield (ton/fed) and Sugar yield (ton/fed).

Data in Table 1 show significant differences among the tested sugarcane genotypes in the number of millable cane $/ \mathrm{m}^{2}$. G.84-47 genotype recorded the highest values for number of millable cane (13.42 and $\left.15.16 / \mathrm{m}^{2}\right)$ and Millable cane length $(260.30$ and $258.40 \mathrm{~cm})$ in both seasons, respectively compared with the other 
genotypes.The variation among sugarcane genotypes in this trait may referred to their variable genetic structures that reflected on their tellering abilities and ability of the formation of internodes and/or determination of their length. Ahmed, 2003) and Ismail and El-Sogheir (2008) obtained significant variations in number of millable cane among sugarcane genotypes. On the other hand, Ahmed, (2003) and Ismail et al (2008) found significant differences among the tested genotypes in millable cane height.

Sugarcane genotype G.98-24 recorded the thickest stalks followed by G.74-96 while G.84-47 genotype had the lowest value of this trait. The superiority of G.98-24 genotype in stalk diameter may controlled by gene make-up, as well as low stand density per unit area (Table 2). Varietals differences in relation to millable cane diameter reported by El-Shafai and Ismail (2006) and Ismail et al (2008) who obtained significant differences among studied genotypes in stalk diameter.

Sugarcane genotype G.98-24 gave the highest values of Brix percentage $(21.49 \%)$ and higher sucrose percentage $(17.74 \%)$ in $1^{\text {st }}$ season, while in $2^{\text {nd }}$ season; G.84-47 genotype had the highest Brix and sucrose percentage $(15.79 \%)$. The differences between the studied genotypes in Brix and sucrose percentage may be due to the variations among genotypes in gene makeup and genetic structure. These results are in harmony with those outlined by Yadav and Sharma (1980), they reported that the differences among genotypes in sucrose, percentages were significant in both seasons.

Sugarcane genotypes grown in $1^{\text {st }}$ season differed significantly in sugar recovery percentage. However, no statistical differences detected among genotypes in this trait in the $2^{\text {nd }}$ season. In the $1^{\text {st }}$ season, G.98-24 genotype markedly surpassed the other genotypes in sugar recovery. The superiority of G.98-24 genotype in this trait could attributed to higher sucrose percentage recorded by that genotype. These results are in agreement with those of El-Shafai and Ismail (2006) and Ismail and El-Sogheir (2008) they found that statistical differences in sugar recovery percentage were recorded among the studied genotypes.

Table 1. Characteristics under investigation in the tested five sugarcane genotypes and their means in two growing seasons

\begin{tabular}{|c|c|c|c|c|c|c|c|}
\hline & $\begin{array}{l}\text { Genotypes } \\
\text { Season }\end{array}$ & G.T.54-9 & G.84-47 & G.74-96 & G.98-28 & G.98-24 & Mean \\
\hline \multirow{2}{*}{$\begin{array}{c}\text { Number of millable } \\
\text { canes } / \mathrm{m}^{2}\end{array}$} & $2010 / 2011$ & 11.88 & 13.42 & 9.41 & 8.15 & 11.38 & 10.85 \\
\hline & $2011 / 2012$ & 11.14 & 15.16 & 10.47 & 10.07 & 13.01 & 11.97 \\
\hline Mean & & 11.51 & 14.29 & 9.94 & 9.11 & 12.19 & 11.41 \\
\hline \multirow{2}{*}{$\begin{array}{l}\text { Millable cane height } \\
(\mathrm{cm})\end{array}$} & $2010 / 2011$ & 228.95 & 260.30 & 186.20 & 221.35 & 208.05 & 221.35 \\
\hline & $2011 / 2012$ & 251.75 & 258.40 & 202.35 & 218.50 & 219.45 & 230.09 \\
\hline Mean & & 240.35 & 259.35 & 194.28 & 219.93 & 213.75 & 225.72 \\
\hline \multirow{2}{*}{$\begin{array}{l}\text { Millable cane } \\
\text { diameter }(\mathrm{cm})\end{array}$} & $2010 / 2011$ & 2.97 & 2.51 & 3.01 & 3.16 & 2.66 & 2.86 \\
\hline & $2011 / 2012$ & 2.81 & 2.44 & 2.93 & 2.95 & 2.77 & 2.78 \\
\hline Mean & & 2.89 & 2.47 & 2.97 & 3.06 & 2.72 & 2.82 \\
\hline \multirow[t]{2}{*}{ Brix $\%$} & $2010 / 2011$ & 21.16 & 20.19 & 19.70 & 21.21 & 21.49 & 20.75 \\
\hline & $2011 / 2012$ & 17.10 & 17.65 & 17.26 & 17.58 & 17.46 & 17.41 \\
\hline Mean & & 19.13 & 18.92 & 18.48 & 19.39 & 19.48 & 19.08 \\
\hline \multirow[t]{2}{*}{ Sucrose $\%$} & $2010 / 2011$ & 16.64 & 16.09 & 16.76 & 16.60 & 17.74 & 16.77 \\
\hline & $2011 / 2012$ & 14.37 & 15.79 & 14.87 & 15.11 & 15.10 & 15.05 \\
\hline Mean & & 15.51 & 15.94 & 15.81 & 15.85 & 16.42 & 15.91 \\
\hline \multirow[t]{2}{*}{ Sugar recovery $\%$} & $2010 / 2011$ & 10.83 & 10.55 & 11.37 & 10.77 & 11.85 & 11.08 \\
\hline & $2011 / 2012$ & 9.70 & 10.98 & 10.15 & 10.31 & 10.33 & 10.29 \\
\hline Mean & & 10.26 & 10.77 & 10.76 & 10.54 & 11.09 & 10.68 \\
\hline \multirow[t]{2}{*}{ Cane yield (ton/fed) } & $2010 / 2011$ & 34.16 & 45.84 & 29.11 & 32.14 & 36.14 & 35.48 \\
\hline & $2011 / 2012$ & 35.88 & 47.52 & 31.53 & 34.12 & 37.64 & 37.34 \\
\hline Mean & & 35.02 & 46.68 & 30.32 & 33.13 & 36.89 & 36.41 \\
\hline \multirow[t]{2}{*}{ Sugar yield (ton/fed) } & $2010 / 2011$ & 3.70 & 4.84 & 3.31 & 3.46 & 4.28 & 3.93 \\
\hline & $2011 / 2012$ & 3.48 & 5.22 & 3.20 & 3.52 & 3.89 & 3.84 \\
\hline Mean & & 3.59 & 5.03 & 3.26 & 3.49 & 4.09 & 3.89 \\
\hline
\end{tabular}


Sugarcane genotype G.84-47 was proven to produce the highest cane yield and sugar yield/fed in both seasons compared with G.T.54-9, G.74-96, G.98-24 and G.98-28 genotypes. The increasing in sugar yield could attributed to higher values of cane yield recorded by G.84-47 genotype These results are in agreement with those reported by Pandey and Shukla (2001) and Ismail and El-Sogheir (2008) they reported that sugar cane genotype G.85-37 surpassed G.T.54-9 genotype in respect to cane and sugar yield.

\section{Genetic estimates}

The sugarcane genotypes under investigation are commercial and promising genotypes that have desired characters. Because of their good characteristics, they would chosen to be as start for breeding programs for developing promised sugar cane genotypes for Egypt and other similar countries, so some of genetic parameters were estimated. Mean of the eight characters under investigation in five sugarcane genotypes average of two seasons tabulated in Table 2 . Variance components, genotypic, coefficient of variations and broad sense heritability of the studied characters for five genotypes of sugar cane are tabulated in Table 3 and analysis of variance are tabulated in Table 4 and As shown from this table the variance due to the interaction of genotype $\mathrm{X}$ year for millable cane highest was 10.711. It was about eighteen times of their corresponding environmental variances of millable cane highest (0.609). A similar results were noted for number of millable (1.025) giving about ten times of their corresponding environmental variance (0.104) also for millable cane diameter (0.017) and brix \% (0.214) which giving about six times of their corresponding environmental variance $(0.003$ and 0.032$)$. This demonstrated the relative contribution of each variance in influencing the phenotype variance (125.45, 6.60, 0.22 and 3.59) of the four characters respectively.

Estimation of broad sense heritability for each cane yield and millable cane diameter $(91.1 \%)$ was the largest one among all characters studied, followed by brix $\%$
(86.6\%). sugar recovery \% (82\%), cane yield $(81.9 \%)$, sugar yield $(81.3 \%)$ and sucrose $\%(81.1)$. This is due to the high genetic variance obtained for these six characters $(0.2,3.11,1.72,33.40,1.52$ and 3.01) respectively. This result suggests that genetic variance was the largest source of total variation for millable cane diameter, brix $\%$, sugar recovery $\%$, cane yield, sugar yield and sucrose $\%$. On the other hand, the variance due to the interaction was proven to be much higher than that of the environmental variances for the six characters respectively. This conclusion suggests that the interaction variances were secondary to the genetic variances in determining the total variability for the previous studied characters $(0.220,3.748,2.094$, $37.107,1.918$ and 3.441) respectively.

The results obtained from estimating of the broad sense heritability for the various traits of sugar cane are in agreement with those obtained by Allam et al (1974), Hogarth (1977), Hoganth and Heing (1981), Singh and Singh (1981), Kang et al (1983), Younan (1997), EITaib et al (2005) and Ghura (2005).

The efficiency of breeding program for improvement of growth, yield and quality properties depends on the extent of genetic variability present in genotypes and the heritability of the concerned characters. The results in Table 3 show variance components, heritability estimate, genotypic and phenotypic coefficients of variability.

The results indicted that phenotypic coefficient of variation (PCV \%) was in harmony with genotypic coefficient of variation (GVC \%) for all studied traits except the number of millable cane, and sugar yield. The data indicated the heritability for number of millable canes and sugar yield were 59.4 and $81.3 \%$ respectively. High genetic coefficients of variation in addition to high heritability reflect the importance for heritable components. The genotypic coefficient of variation (GCV \%) values were 16.49 and $28.67 \%$ for the 2 characters, respectively.

Table 2. Mean of the eight characters under investigation in five sugarcane genotypes average of two seasons (2006/2007- 2007/2008)

\begin{tabular}{lcccccccc} 
Genotypes & $\begin{array}{c}\text { No. } \\
\text { millable } \\
\text { canes }\end{array}$ & $\begin{array}{c}\text { Millable } \\
\text { cane } \\
\text { height }\end{array}$ & $\begin{array}{c}\text { Millable } \\
\text { cane } \\
\text { diameter }\end{array}$ & $\begin{array}{c}\text { Brix } \\
\text { \% }\end{array}$ & $\begin{array}{c}\text { Sucrose } \\
\text { \% }\end{array}$ & $\begin{array}{c}\text { Sugar } \\
\text { recovery } \\
\text { \% }\end{array}$ & $\begin{array}{c}\text { Cane } \\
\text { yield }\end{array}$ & $\begin{array}{c}\text { Sugar } \\
\text { yield }\end{array}$ \\
\hline G.T.54-9 & 11.51 & 240.35 & 2.89 & 19.13 & 15.51 & 10.26 & 35.02 & 3.59 \\
G.84-47 & 14.29 & 259.35 & 2.47 & 18.92 & 15.94 & 10.77 & 46.68 & 5.03 \\
G.74-96 & 9.94 & 194.28 & 2.97 & 18.48 & 15.81 & 10.76 & 30.32 & 3.26 \\
G.98-28 & 9.11 & 219.93 & 3.06 & 19.39 & 15.85 & 10.54 & 33.13 & 3.49 \\
G.98-24 & 12.19 & 213.75 & 2.72 & 19.48 & 16.42 & 11.09 & 36.89 & 4.09 \\
Mean & 11.41 & 225.72 & 2.82 & 19.08 & 15.91 & 10.68 & 36.41 & 3.89 \\
\hline
\end{tabular}


Table 3.Variance components, heritability, genotypic and coefficient of variations for the studied character

\begin{tabular}{lcccccccc}
\hline \multicolumn{1}{c}{ Parameters } & Mean & $\boldsymbol{\delta}^{\mathbf{2}} \mathbf{g}$ & $\boldsymbol{\delta}^{\mathbf{2}} \mathbf{y}$ & $\boldsymbol{\delta}^{\mathbf{2}} \mathbf{c}$ & $\boldsymbol{\delta}^{\mathbf{2}} \mathbf{p h}$ & $\begin{array}{c}\mathbf{G C V} \\
\mathbf{\%}\end{array}$ & $\begin{array}{c}\mathbf{P C V} \\
\mathbf{\%}\end{array}$ & $\mathbf{h}^{\mathbf{2}}$ \\
\hline $\begin{array}{l}\text { Number of } \\
\text { millable canes }\end{array}$ & 11.41 & 3.92 & 1.025 & 0.104 & 6.60 & 16.49 & 21.39 & 59.4 \\
\hline $\begin{array}{l}\text { Millable cane } \\
\text { height }\end{array}$ & 225.72 & 82.91 & 10.711 & 0.609 & 125.45 & 3.84 & 4.72 & 66.1 \\
\hline $\begin{array}{l}\text { Millable cane } \\
\text { diameter }\end{array}$ & 2.82 & 0.2 & 0.017 & 0.003 & 0.22 & 15.06 & 15.77 & 91.1 \\
\hline Brix \% & 19.08 & 3.11 & 0.214 & 0.032 & 3.59 & 9.62 & 10.34 & 86.6 \\
\hline Sucrose \% & 15.91 & 3.01 & 0.321 & 0.213 & 3.71 & 10.36 & 11.51 & 81.1 \\
\hline Sugar recovery \% & 10.68 & 1.72 & 0.068 & 0.832 & 2.10 & 11.66 & 12.88 & 82.0 \\
\hline Cane yield & 36.41 & 33.4 & 1.920 & 0.781 & 40.79 & 15.08 & 16.67 & 81.9 \\
\hline Sugar yield & 3.89 & 1.52 & 0.200 & 0.249 & 1.87 & 28.67 & 31.80 & 81.3 \\
\hline
\end{tabular}

Table 4. Analysis of variance for the studied characteristics

\begin{tabular}{lcllllllll}
\hline & & \multicolumn{8}{c}{ Mean Square } \\
\cline { 3 - 9 } \multicolumn{1}{c}{ Source } & D.f & $\begin{array}{c}\text { No. } \\
\text { millable } \\
\text { canes }\end{array}$ & $\begin{array}{c}\text { Millable } \\
\text { cane } \\
\text { height }\end{array}$ & $\begin{array}{c}\text { Millable } \\
\text { cane } \\
\text { diameter }\end{array}$ & $\begin{array}{c}\text { Brix } \\
\%\end{array}$ & $\begin{array}{c}\text { Sucrose } \\
\%\end{array}$ & $\begin{array}{c}\text { Sugar } \\
\text { recovery } \\
\text { \% }\end{array}$ & $\begin{array}{c}\text { Cane } \\
\text { yield }\end{array}$ & $\begin{array}{c}\text { Sugar } \\
\text { yield }\end{array}$ \\
\hline Year (Y) & 1 & 8.106 & 139.378 & 0.08 & 215.11 & 201.253 & 189.98 & 439.132 & 0.198 \\
R(y) & 4 & 2.624 & 503.311 & 0.223 & 64.722 & 98.373 & 482.726 & 535.479 & 0.687 \\
Genotypes (G) & 4 & 82.879 & 1606.841 & 3.75 & 59.87 & 55.981 & 32.96 & 643.846 & 28.12 \\
YG & 4 & 1.898 & 35.85 & 0.047 & 2.099 & 0.47 & 0.846 & 9.192 & 0.084 \\
Error & 16 & 0.601 & 102.186 & 0.032 & 1.134 & 1.588 & 1.09 & 16.432 & 0.164 \\
\hline
\end{tabular}

As for phenotypic coefficient of variation (PCV \%) values were 21.39 and $30.8 \%$ for number of millable cane and sugar yield respectively. Burton (1952) suggested that a genetic coefficient of variation together with heritability would give the best indication of the genetic advance to be expected from selection. This study suggest that the improvement of sugarcane genotypes will have genetic progress in number of millable canes, cane yield and sugar yield than the other studied characters which possessed low genetic variability.

\section{REFERENCES}

A.O.A.C. (1995). Official methods of analysis. Puplished by the A.O.A.C., Box 540, Washington, D.C., USA.

Ahmed, A. Z. (2003). Assessment of the optimum nitrogen level and seeding rate for two promising sugar cane genotypes. Egypt. Appl. Sci., 18 (6-B): 559-573

Allam, A.I. ; P.E. Schilling and K.L. Koone (1974). Estimates of heritability in sugar cane, The Sugar Journal vol. 36 (10): 35-37.

Burton, G. W. (1952) Quantitative inheritance in grass. Proc. $6^{\text {th }}$ Int. Grassland Congr. 1: 227-783. (C.F. Gupta, S.P., T. H. Singh and P.S. Phul. 1972. Indian J. Agric. Sci., 42(3):215-218)
Chang Y.S. (1996). Estimating heritability of and correlations among Brix, Purity, and sugar content in sugar cane using balanced multiple location and year data. Rep. Taiwan Sugar Res. Inst. 151: 1-10. (Cited from Ghura 2005)

Comstock, R.E. and R.H. Moll (1963) Genotypeenvironmental interaction, PP. 164- 196. In W. D. Hanson and H.F. Robinson. Statistical Genetics and plant breeding. NAS-NRC pub. 982. (Cited from Ghura 2005).

El-Shafai, A.M.A. and A.M.A. Ismail (2006). Effect of row spacing on yield and quality of some promising sugarcane genotypes. Egypt J.Appl. Sci., 21 (11): 32-46.

El-Taib. A.B.A; M.Z. El-Hifny ; E.E.S. Mahdy and A.M. Abu- Salama (2005) Performance of some selected sugar cane genotypes in two Upper Egypt locations. International Conference on: political, Economic and Technological challenges for sugar and its Integrated Industries in the Arab Region, the Middle East. Africa and the European union" 306 April 2005, Alex, Egypt poster No,6.

Hogarth . k. k. wu .and D.J Heing (1981). Estimating genetic variance in sugarcane using a factorial cross design. Crop Sci. 21:21-25

Hogarth, D. M. (1977) Quantitative inheritance studies in sugarcane III. The effect of competition and violation of genetic assumptions on estimation of genetic variance components. Aust. J. Agric. Res . 28:257-268 
Ismail, A.M.A. and K.S. El-Sogheir (2008). Seed setts of plant and ratoons crop in relation to varietal performance of three sugarcane genotypes. Egypt J. Appl. Sci., 23 (2): 500 - 513 .

Ismail, A.M.A.; M.A. Bekheet and A.S. Abo El-Hamd (2008). Yield and quality of four sugarcane genotypes as influenced by seed rate and nitrogen fertilization. Egypt $\mathrm{J}$. Appl. Sci., 23 (1): 107-123.

Kang. M S; J. D. Miller and P.Y.P. Tai (1983).Genetic and phenotypic path analysis and heritability in sugar cane. Crop Sci 23:643-647

Kang. M S; J. D. Miller and P.Y.P. Tai, J. L. Dean, and B. Glaz (1987) Implications of confounding genotype x year and genotype $\mathrm{x}$ crop effects in sugar cane. Field Crops Res. 15: 349.355.

Miller, J.C., S.A. Williams and H.F. Robenson (1959) Genotype-environmental interaction and their implication on testing methods. Agron. J. 51: 132-135.

Ghura, Nabawya S.A. (2005) Heritability in sugarcane (Saccharum officinarum L.). Alex. Science Exchange Journal. Vol. 26, No. 4 Oct. - Dec.

Pandey, M. B.; Shukla (2001). Response of sugarcane (Saccharum species) hybrid complex to planting seasons and nitrogen levels. Indian J. Agric. Sci 71: 261-263.
Ramesh, V. and Sumamsusan-Varghese (2003). Effect of fertilizer levels of $\mathrm{N}, \mathrm{P}$ and $\mathrm{K}$ on the yield and juice quality of sugarcane. Indian. Sugar. 53(3): 175-177.

Shafshak, S.A.; I.H. El-Geddawy; S.A.H. Allam and G.S. ElSayed (2001). Effect of planting densities and nitrogen fertilizer on: 1. Growth criteria, juice quality and chemical constituents of some sugar cane genotypes. Pakistan Sugar J., 16(4): 2-11.

Singh, H.N.; Singh, T.K. (1981) Selection parameters in sugar cane. Indian Journal of Agricultural Sciences. 51 (8):562566 (En. 13 ref.) up counc. Sugar Cane Res. Shahjahanpur, U.P. India (Cited from Ghura 2005)

Snedecor, G.W. and W.G. Cochran (1981). Statistical Methods. Seventh Ed., Iowa State Univ. Press, Ames, Iowa, USA.

Yadav, R.L. and R.K. Sharma (1980). Effect of nitrogen level and harvesting date on quality characteristics and yield of four sugar cane genotypes. Indian J. Agric. Sci., 50: 581589.

Younan, N.Z.; M. A. El-Deeb and N.M. EL-Talkhawy(1997) Estimation of genetic variance and broad sense heritability for some characters of sugar cane (Saccharum officinarum L.). Adv. Agric. Res. Vol. 2, No.1 


\section{الملخص العربي}

\section{تقدير التباين الوراثى والقدرة على التوريث فى المدى الواسع فى قصب السكر}

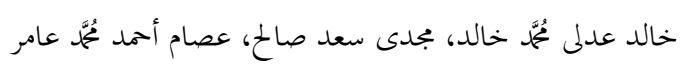

أجريت هذه الدراسة بكحطة بحوث الجيزة بالجيزة خلال موسمي

ونسـبة السـكر القابـل للأسـتخلاص في الموســم الأول للصـنف

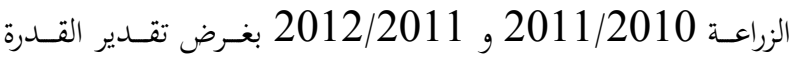

.G.98-24

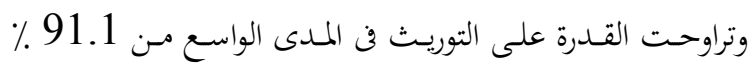

على التوريث فن المدى الواسع عن طريق تقدير الاختلافات الوراثية

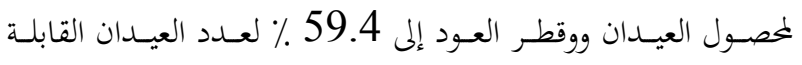

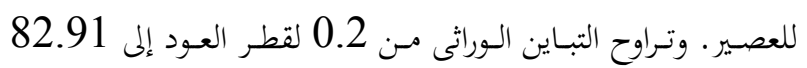

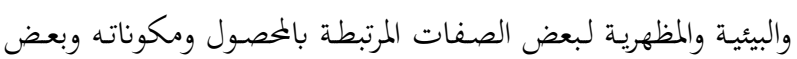

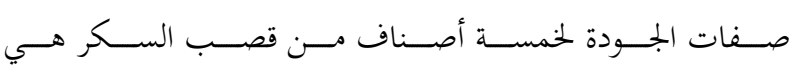
G.T.54-9, G.84-47, G74-96, G.98-24, G.98-28

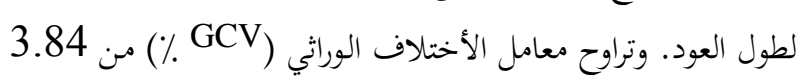

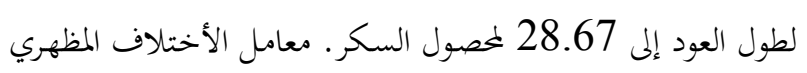
تراوح بين 4.72 ٪ لطول العود إلى 31.8 لمصول السكر . تشير هـذه الدراسة إلى أمكانية التحسين الوراثى بدرجـة كبيرة

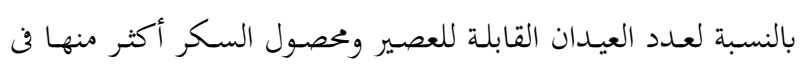

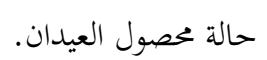

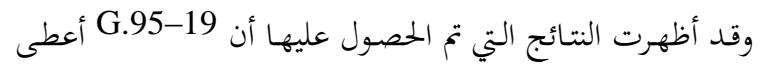

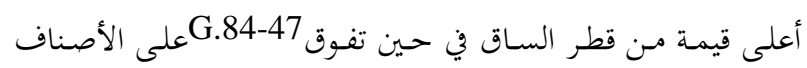

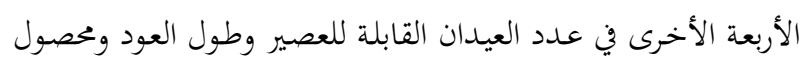

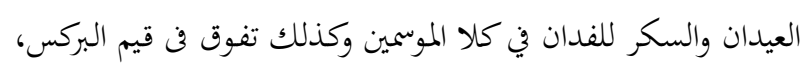

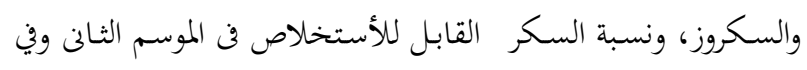

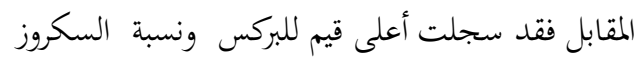

